\title{
Folic Acid-Targeted Disulfide-Based Cross-Linking Micelle for Enhanced Drug Encapsulation Stability and Site-Specific Drug Delivery Against Tumors [Corrigendum]
}

Zhang $\mathrm{Y}$, Zhou J, Yang $\mathrm{C}$, et al. Int J Nanomedicine. 2016;11:1119-1130.

The authors have advised due to an error at the time of figure assembly, Figure 4 on page 1124 is incorrect. The correct Figure 4 is as follows.

A

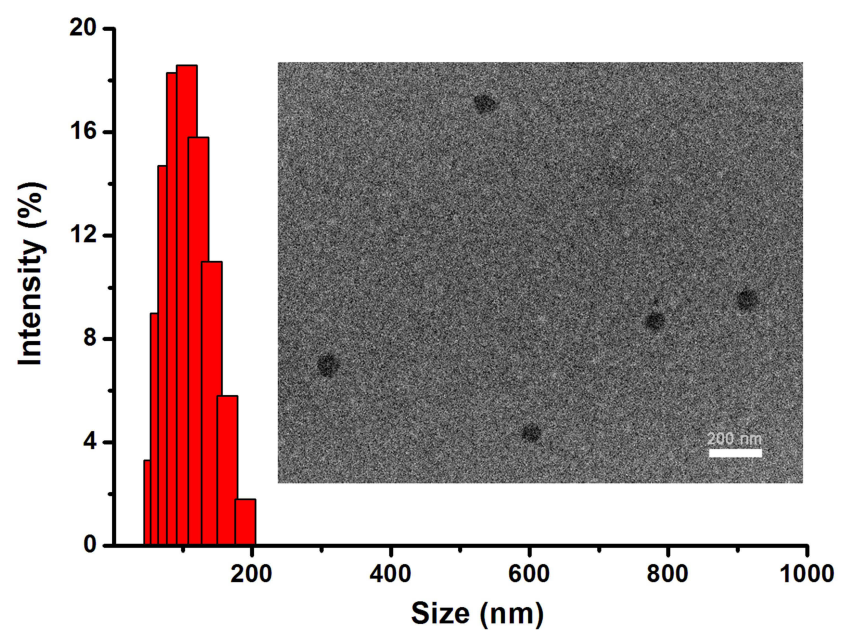

Page 1126, Table 1, the authors have advised a mistake was made in calculating the Drug loading content (DLC) in the manuscript. The correct Table 1 is as follows.

The authors apologize for these errors and advise it does not affect the results of the paper.

\section{B}

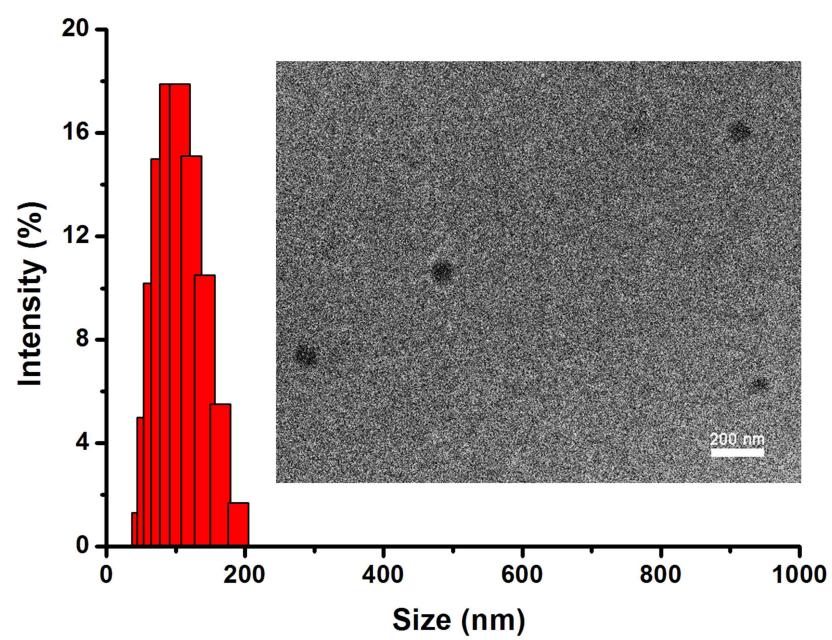

Figure 4 Size distribution and morphology of NCM and CCM.

Notes: Size distribution and morphology of NCM (A) and CCM (B) measured by DLS and TEM.

Abbreviations: DLS, dynamic light scattering; TEM, transmission electron microscope; NCM, noncross-linked micelle; CCM, cross-linked micelle. 
Table I Chemical Characters of Different Cur Loaded Micelles

\begin{tabular}{|l|l|l|l|l|}
\hline Sample & Size (nm) & PDI & DLC (\%) & DLE (\%) \\
\hline NCM-Cur & $103 \pm 3.2$ & $0.35 \pm 0.33$ & 7.62 & 82.53 \\
CCM-Cur & $100 \pm 2.6$ & $0.42 \pm 0.30$ & 7.71 & 83.49 \\
FA-CCM-Cur & $108 \pm 3.5$ & $0.46 \pm 0.42$ & 7.67 & 83.06 \\
\hline
\end{tabular}

Note: Results are expressed as the mean \pm SD $(n=3)$.

\section{Publish your work in this journal}

The International Journal of Nanomedicine is an international, peerreviewed journal focusing on the application of nanotechnology in diagnostics, therapeutics, and drug delivery systems throughout the biomedical field. This journal is indexed on PubMed Central, MedLine, CAS, SciSearch ${ }^{\mathbb{R}}$, Current Contents ${ }^{\mathbb{R}} /$ Clinical Medicine, $^{-}$
Journal Citation Reports/Science Edition, EMBase, Scopus and the Elsevier Bibliographic databases. The manuscript management system is completely online and includes a very quick and fair peer-review system, which is all easy to use. Visit http://www.dovepress.com/ testimonials.php to read real quotes from published authors. 